\title{
Kommentar til Janne Flyghed
}

\author{
Af Per Ole Träskman ${ }^{1}$
}

Professor Janne Flyghed sätter fullt berättigat ett stort rött kryss i marginalen för mitt konstaterande att det inte finns »någon anledning att inte acceptera den begreppsbestämning som finns i EU:s rambeslut av den 13 juni 2002 om bekämpande av terrorism«. Formuleringen är olycklig och därför vilseledande.

Jag anser att det finns god anledning att kritisera EU:s definition av terrorism liksom också en hel del andra definitioner som har presenterats under årens lopp. Det har jag själv gjort upprepat i flera tidigare artiklar, första gången i denna tidskrift år 1986, s. 452-464. I min artikel om möjligt samband mellan ekonomisk brottslighet, organiserad brottslighet och terrorism tog jag inte upp detta tema. Jag utgick helt enkelt från den terrorismdefinion som används av myndigheterna $\mathrm{i}$ EU:s medlemsstater. Vad jag avsåg var alltså bara att det inte finns skäl att ifrågasätta att det är EUs terrorismbegrepp som idag är det som accepteras och används vid brottskontrollen i alla EU-stater. Flygheds kritik av begreppet är i och för sig viktig och befogad.

\section{Note}

1. Per Ole Träskman (LL.D., doctor hc.) is senior professor of Criminal Law at the University of Lund (Sweden) and associate professor of criminal law and criminal procedure at the University of Helsinki. 